\title{
Supplementation of maize-based concentrates and milk production in indigenous cows
}

\author{
M. M. Kamal1*, D. M. H. Iqbal and A. B. M. Khaleduzzaman ${ }^{2}$ \\ Market Developments and Service Provision, SAAKTI Project, Inter-cooperation, Bogra, \\ Bangladesh
}

\begin{abstract}
The effect of feeding maize-based concentrates on milk yield in cows with costbenefit analysis was done at smallholder farms in four districts of northern Bangladesh. Concentrate mixtures containing wheat bran, rice polish and sesame oil cake were supplied to 40 indigenous (Desi) cows (20 in Group A and 20 in Group B) for 30 days before intervened feeding. Cows were given $1 \mathrm{~kg}$ maize-based concentrates $/ 100 \mathrm{~kg}$ body weight twice daily for a further 60 days after feeding intervention. Cows' body weight, milk yield and farm income were recorded before and after maze-based concentrate supplementation. Milk production is increased by $30 \%$ for Group A and $90 \%$ for Group B. The difference in milk yield before and after supplementation of maize-based concentrate in Group B was significant $(\mathrm{P}<0.05)$. The cows' average body weights in Group A increased by $4.7 \mathrm{~kg}$ and in Group B by $1.8 \mathrm{~kg}$. In both groups, net income increased and the income increase in A was significantly $(\mathrm{P}<0.01)$ greater than in $\mathrm{B}$. Maize-based concentrated feeding in cows led to better milk yield with good economic return. (Bangl. vet. 2009. Vol. 26, No. 2, 48-53)
\end{abstract}

\section{Introduction}

Dairying is an integral part of rural livelihoods especially for the landless and smallholder dairy farmers, and acts as an important economic activity in Bangladesh; it provides supplementary income, employment and nutrition to about 3.6 million households (Marks and Sultana, 2008). More than $80 \%$ of people are involved in rearing cattle, most of the cattle are nondescript indigenous Zebu-type animals (Khan, 2006). Productivity of such indigenous animals is low, which is an important constraint limiting the development of the dairy industry. The production level of these animals is far behind the stakeholders' expectations to make the industry competitive. The reason is poor genetic characteristics. Poor nutrition might be a second cause.

The total milk production of the country is 2 million tonnes per year, which is insufficient to meet existing demand in Bangladesh. Daily consumption is about $35 \mathrm{ml}$ per capita, while $250 \mathrm{ml}$ is recommended. Milk production costs are high due to high feed costs. There is limited access to milk marketing, processing costs are higher than in neighbouring countries and technology uptake has been minimal.

\footnotetext{
${ }^{1 \& 2}$ Department of Livestock Services, Dhaka, Bangladesh

*Correspondence: E-mail:- dmmkamal@hotmail.com
} 
Animals are mainly kept in stalls with limited grazing on the roadside, embankment slopes, seasonal fallow lands etc. Fibrous crop residues constitute an important source of feed for dairy cattle (Debnath et al., 2003). Paddy (rice) straw is the main source of roughage among the crop residues. Green roughage and rice polish are also widely fed to cows under village conditions. Maize grain is now available due to an increase in production in recent years. Total maize production increased by 63\% from 2001 to 2008 (Khaleduzzaman and Khandaker, 2009). Therefore, farmers can supply dairy cows with crushed maize in addition to rice polish, wheat bran, and oil cakes. But there is scant information regarding the proportion of ingredients in concentrate feeds and nutritional demand of cows with regard to milk production at village level. Many feed manufacturing companies are preparing concentrate feed mixtures and supplying large dairy farmers, but smallholders are unable to buy because of high prices. This study was undertaken to measure the effect of supplementary maize-based concentrate feeding on milk yield of indigenous cows under village conditions and the cost-benefit analysis.

\section{Materials and Methods}

\section{Location and animals}

This study was conducted in four districts of northern Bangladesh between April and June 2009. A total of 40 indigenous cows (10/district) were selected from 40 farms. Farms had a mean of 4.5 animals with 1.1 lactating cows. The age of the cows ranged from 4 to 5 years and their parity from 3 to 5 . Body condition score (BCS) ranged between 2.5 to 3.0 and body weights from 110 to $160 \mathrm{~kg}$. All animals had been lactating 2 to 4 months. The animals were in two groups: Group A (20 cows: 10 from Sirajgonj and 10 from Joypurhat) and Group B (20 cows: 10 from Gaibandha and 10 from Rangpur).

\section{Experimental procedure}

In both groups, the animals were fed basal roughages (straw and green grass) with concentrates ( $1 \mathrm{~kg}$ for $100 \mathrm{~kg}$ body weight) made of rice bran, wheat bran, sesame oil cake, molasses, common salt and vitamin-mineral premixes for 30 days before feeding intervention followed by 60 days fed basal roughages with concentrates only after replacing of wheat bran by maize grain after feeding intervention (Table 1).

The ingredients and chemical composition of traditional and test feeds are in Table 2. Concentrated feeds were given twice daily. One $\mathrm{kg}$ concentrated feed was provided per $100 \mathrm{~kg}$ body weight, and ad libitum water. The cows were milked twice daily with their calves at foot. Both groups were maintained under identical management.

\section{Data collection and statistical analysis}

Data were recorded for 30 days before feeding intervention and 60 days after maize-based concentrate supplementation. Daily milk yield was recorded. 
Table 1. Composition of concentrate feeds before and after intervention

\begin{tabular}{l|c|c}
\hline \multicolumn{1}{c}{ Ingredient (\%) } & Before intervention & After intervention \\
\hline Maize (crushed) & - & 25.0 \\
Rice bran (polish) & 50.0 & 40.0 \\
Wheat bran & 15.0 & - \\
Sesame oil cake & 25.0 & 25.0 \\
Molasses & 08.0 & 08.0 \\
Salt & 01.0 & 01.0 \\
Vitamin-mineral premix & 01.0 & 01.0 \\
\hline
\end{tabular}

Table 2. Chemical composition (g/100 gm) of dietary feeds before and after intervention

\begin{tabular}{l|c|c}
\hline & Before intervention & After intervention \\
\hline Rice straw & 38.2 & 38.2 \\
Green grass & 33.3 & 33.4 \\
Maize crushed & - & 7.2 \\
Wheat bran & 4.4 & - \\
Rice bran (polish) & 14.6 & 11.7 \\
Sesame oil cake & 7.2 & 7.2 \\
Molasses & 2.3 & 2.3 \\
Salt & 0.01 & 0.01 \\
Vitamin-mineral premix & 0.01 & 0.01 \\
\hline Chemical composition and nutritive value & & \\
DM (g/100 g) & 3.0 & 3.0 \\
CP (g/ kg DM) & 96.1 & 91.9 \\
ADF (g/100 g) & 43.7 & 42.6 \\
NDF (g/100 g) & 62.0 & 62.1 \\
Ash (g/100 g) & 13.6 & 13.1 \\
ME (MJ/kg DM) & 8.6 & 8.8 \\
\hline
\end{tabular}

* Estimated

Changes in net income before and after intervention were calculated to make the cost-benefit analysis, determined by the formula \{Income from milk (milk production $\times$ milk price) - milk production cost (feed intake $\times$ feed cost) . Body weight of the animals was estimated according to the Shaeffer's formula adopted by McNitt (1983):

Body weight $(\mathrm{kg})=\frac{\text { Length }(\text { inch }) \times(\text { Girth in inch })^{2}}{660}$

Where length $=$ Point of shoulder to buttock, and girth $=$ Circumference of chest just behind forelimb. 
The basal roughage and concentrate supplements were analysed for proximate principles (AOAC, 2000) and fibre fraction was analysed as described by Goering and Van Soest (1970). The data were entered into Microsoft Excel work sheet (2003) and exported to SPSS (Version 10.0, 1999) for analysis. Descriptive statistics were computed and Paired t-test was done to detect the changes in milk production, body weight and net income per cow per day after supplementary feeding.

\section{Results and Discussion}

Initial milk production of the cows in group A was $3.6 \pm 1.8$ litres per cow per day and increased by $1.2 \pm 0.2$ litres after supplementation, an increase of $30 \%$; however, the difference was not significant ( $P>0.05$, Table 3 ). For group $B$, average milk production of the cows was $0.8 \pm 0.4$ litres per cow per day before supplementation and increased by $0.7 \pm 0.1$ litres after, an increase of $90 \%$. The difference was significant $(\mathrm{P}<0.05$, Table 3$)$.

Table 3. Changes in milk production $(\mathrm{L} / \mathrm{d})$ and cows' body weight $(\mathrm{kg})$ before and after feeding intervention

\begin{tabular}{ccccc}
\hline Group* & $\begin{array}{c}\text { Before intervention } \\
(\text { Mean } \pm \text { SD) }\end{array}$ & $\begin{array}{c}\text { After intervention } \\
(\text { Mean } \pm \text { SD) }\end{array}$ & P value \\
\hline Milk production (L/d) & & & \\
A & $3.8 \pm 1.8$ & $4.9 \pm 1.6$ & 0.38 \\
B & $0.8^{\mathrm{b}} \pm 0.4$ & $1.6^{\mathrm{a}} \pm 0.4$ & 0.03 \\
\hline Cow's body weight (kg) & & & \\
A & $133.1 \pm 14.7$ & $137.8 \pm 13.6$ & 0.61 \\
B & $121.4 \pm 13.1$ & $123.2 \pm 14.2$ & 0.84 \\
\hline
\end{tabular}

${ }^{*}$ Number of cows in each group $=20 ; \mathrm{a}, \mathrm{b}$ Values in the same row differ significantly $(\mathrm{P}<0.05)$

In group A, Pabna type cows (special type of indigenous cows having higher genetic merit) had higher initial milk yield. Group B consisted of local indigenous cows and their initial milk yield was lower due to poor genetic merit. Milk production increased in both groups after maize-based concentrate supplement was fed. Similar findings were reported by Chandrasekharaiah et al. (2004) who used a ration based on finger millet straw with maize grain supplementation. Pathak and Pandey (1995) reported higher milk yield in crossbred cows fed with higher levels of maize grain along with ad libitum berseem fodder.

The type of carbohydrate and nitrogen included in the ration that influences milk production (Clark and Davis, 1980). Jilg and Hirsch (1996) showed that maize starch differs from other cereal starches such as barley and wheat in its degradation; $60 \%$ of maize starch being degraded in the rumen compared with $90 \%$ of barley and wheat starch (Sampath et al., 1999). In the present experiment, wheat bran was replaced by maize grain, which is slowly degraded, to match energy requirements for the rumen microbes for better digestibility of roughage. Replacement of wheat 
bran with crushed maize enhanced the energy level, which could have contributed to higher milk production (Sampath et al., 1999). Sivaiah and Mudgal (1983) reported that the escape of $20-40 \%$ maize starch from rumen fermentation followed by its absorption in the lower tract increased milk production. However, the increase in milk yield was $60 \%$ greater in group B than group A, which indicates that local indigenous cows of Group B responded better to supplementary maize-based concentrate than indigenous Pabna type cows in Group A.

The body weights of the cows of both group increased after feeding maize concentrate (Table 3). The cows gained 4.7 and $1.8 \mathrm{~kg}$ on average in Group A and B, respectively. However, body weight was higher in Group A: this might be due to the type of cows. The result is similar to that of Debnath et al. (2003), who reported that average total body weight gain was 1.3 to $6.0 \mathrm{~kg}$ per cow during 91 days.

In Group A, farmers' net income/cow/day increased from $101.3 \pm 57.8$ to $128.8 \pm$ 57.3 Taka (Table $4 ; 1 \$=$ Taka: 69 ). For group B, the net income increased from $5.2 \pm$ 4.1 to $13.5 \pm 4.4 \mathrm{Taka} / \mathrm{cow} /$ day. The increase in net income was significantly greater in Group A ( $<<0.01$, Table 4) than Group B. Net income increased in both groups. Milk yield was higher in Group B due to higher genetic merit. Milk price was higher in the area of Group A than B. The result of this study is comparable with Shamsuddin et al. (2009), who reported that community-based dairy veterinary services increased farmers' income by Taka: 524 to 1635 per cow per month. In the present study, however, only supplementary maize-based concentrate feeding was provided, whereas community-based dairy veterinary services included health care, feeding and training.

Table 4. Changes in farmers' net income (Taka)/cow/day following supplementary maize-based concentrate feed ( $1 \$=$ Taka : 69)

\begin{tabular}{c|c|c|c|c}
\hline Group $^{*}$ & $\begin{array}{c}\text { Net income (N1) per cow } \\
\text { per day before intervention } \\
(\text { Mean } \pm \text { SD) }\end{array}$ & $\begin{array}{c}\text { Net income (N2) per cow } \\
\text { per day after intervention } \\
(\text { Mean } \pm \text { SD) }\end{array}$ & $\begin{array}{c}\text { Change (N2-N1) in } \\
\text { farmers' net income } \\
(\text { Mean } \pm \text { SD) }\end{array}$ & P value \\
\hline A & $101.3 \pm 57.8$ & $128.8 \pm 57.3$ & $27.5^{\mathrm{a}} \pm 8.0$ & 0.003 \\
B & $5.2 \pm 4.1$ & $13.5 \pm 4.42$ & $8.3^{\mathrm{b}} \pm 2.3$ & \\
\hline
\end{tabular}

* Number of cows in each group = 20; a, b Values in the same column differ significantly $(\mathrm{P}<0.01)$

\section{Conclusions}

Maize-based concentrated feeding increased milk production and net income. The maize-based ration proved cost-effective in promoting milk production in small dairy farms.

\section{Acknowledgements}

The author would like to acknowledge Inter-cooperation Regional Team of Bogra for funding support, Livestock Service Providers for collecting data and farmers for providing their cows to complete the study successfully. 


\section{References}

AOAC 2000: Official Methods of Analysis. 17th edn. Association of Official Analytical Chemists, Washington, DC, USA.

Chandrasekharaiah M, Sampath KT, Praveen US 2004: Effect of strategic supplementation of finger millet straw on milk yield in crossbred cows - On-farm trial. Indian Journal of Poultry Science 57 192-197.

Clark JH, Davis CL 1980: Some aspects of feeding high producing dairy cows. Journal of Dairy Science 63 873-891.

Debnath GK, Kobar AKMAH, Chanda T, Hoque MA, Halim MA 2003: Effect of supplementary concentrate feeding on milk production, quality and body weight changes of Red Chittagong cows and their calves under village management conditions. Pakistan Journal of Biological Sciences 6 945-947.

Goering HK, Van Soest PJ 1970: Forage Fiber Analysis. Handbook No. 379. ARS, USDA, Washington, DC, USA.

Jilg T, Hirsch P 1996: Maize grain as energy source in cattle feeding. Mais 3 112-113.

Khaleduzzaman ABM, Khandaker ZH 2009: Commercial feed production and quality control: Present status and future prospects in Bangladesh. In: Proceedings of the $6^{\text {th }}$ International Poultry Show and Seminar, WPSA-BB, Dhaka, Bangladesh pp: 12-15.

Khan MS 2006: Community Extension Workers Training Guide, Participatory Livestock Development Project (PLDP), Department of Livestock Services, Dhaka, Bangladesh.

Marks M, Sultana MT 2008: Char Livelihood Programme: Economic Impact of Cattle Transfers during the CLP's Assets Transfer Programmes (2006-2008); Innovation, Monitoring \& Learning Division, Maxwell Stamp PLC, Dhaka, Bangladesh.

McNitt JL 1983: Livestock Husbandry Techniques. $1^{\text {st }}$ edn. The English Language Book Society and Granada, London, UK.

Pathak NN, Pandey HN 1995: Effect of feeding different levels of cereal grain with ad libitum berseem fodder on the performance of crossbred lactating cows. Indian Journal of Dairy Science 48 540-542.

Sampath KT, Chandrasekharaiah M, Anandan S, Thulasi A 1999: Bypass Protein for Ruminants, Technical Bulletin No. 2, National Institute of Animal Nutrition and Physiology, Bangalore, India.

Shamsuddin M, Talukder AK, Kabir MS, Rahman MB, Amin MR, Alam MM 2009: Integrated approach for improving the productivity of native cattle and buffaloes at Mymensingh, Bangladesh. International Conference on Quality Seed and Food Security, 17-19 February, Bangladesh Agricultural University, Mymensingh, Bangladesh pp. 76-77.

Sivaiah K, Mudgal VD 1983. Effect of feeding different levels of protein and energy on feed utilization and milk production in buffaloes. Indian Journal of Dairy Science 36 85-92. 